\title{
EFFECT OF OZONE ON PRESERVATION OF CHILLED CHICKEN
}

\author{
HANAN A. EL DAHSHAN, TAGHREED A. HAFEZ and HANAN A. EL GHAYATY
}

Animal Health Research Institute, Department of Food Hygiene, Port- Said Lab

\section{ABSTRACT}

Received at: 10/12/2012

Accepted: 14/1/2013
The effects of gaseous ozone treatment on microbial counts and shelf life of chilled boneless chicken breasts as well as the influence of ozone on chicken quality properties such as color, odor, and texture were studied. Treatment of chicken breasts with 40, 60, and $70 \mathrm{ppm}$ of gaseous ozone for 20 minutes efficiently reduced the populations of Total aerobic bacterial count, Coliforms, and Total mould counts and prolonged the shelf life of the chicken breasts more than 9 days. Immediately after ozone treatment panelists were unable to detect any color, odor or texture differences between the ozonated and control groups but with storage time ozonated groups seemed to had better quality as compared with nonozonated group. Thus, at the ozone concentrations and exposure times used in this study, ozone effectively reduced the population of spoilage bacteria contaminating the chicken breasts yet had no adverse effects on their quality characteristics.

Key words: Ozone, chilled chicken, bacterial count

\section{INTRODUCTION}

Chicken meat have been widely consumed especially in the recent years due to its low fat content, fast preparation, and being more economical than red meat. Chicken meat is being sold as whole or as pieced depending on the demands of the consumers (Cevger et al., 2002). There is an increase on the pieced chicken demand especially in large cities (Şengör, 2002).

Microorganisms that are present in chicken's interior organs, skin surface and feather, can easily contaminate the meat during poultry processing steps. Contamination is mostly seen at steps of scalding, plucking, and evisceration. In addition cross contamination in the carcasses, dirtiness of the processing water and equipments increase the contamination level in the processing steps (Tosun and Tamer 2000; Anonymous, 2002).

In order to prevent the microbial contamination of the chicken meat, methods like cooling, vaporvacuum system, vapor pasteurization are being used (Allen et al., 2000). Along with this, chemicals like chlorine and chlorine compounds (Erickson, 1999), ozone (Chang and Sheldon, 1989; Whistler and Sheldon, 1989), organic acids (Anonymous, 2002), trisodium phosphate (Rio et al., 2006) are being widely used for decontamination purposes.

Food researchers are trying to discover an alternative cleaning and sanitizing agents effective against food spoilage and pathogenic bacteria, harmless to humans and environment. Ozone (O3) is effective against the majority of microorganisms tested by numerous research groups. Relatively low concentrations of ozone and short contact time are sufficient to inactivate Gram positive and Gram negative bacteria, fungi and fungal spores, parasites and viruses (Guzel- Seydim et al., 2004), even though it does not leave any harmful residues due to quick decomposition to a non toxic product $(\mathrm{O} 2)$.

Ozone is produced by passing gaseous oxygen through a high voltage electrical field at ambient or refrigerated temperatures (Graham 1997; Horvath et al., 1985). The resulting gas is a more effective sanitizer than chlorine. Ozone has been used for decades in many countries, the USDA 1997 granted ozone, generally recognized as safe (GRAS)and in 2001 the FDA officially approved media containing ozone for use in the food industry, also for direct contact with food products, including fish, meat and poultry (Mielcke and Ried, 2004; Vaz-Velho et al., 2006 and Zentox, 2007).

Ozone can be used in its gaseous or aqueous state; this flexibility makes it a viable option for application on easy to damage products (Perry and Yousef, 2011).

It has been proposed that ozone destroys microorganism by the progressive oxidation of vital cellular components. The bacterial cell surface has been suggested as the primary target of ozonation. Two major mechanisms have been identified in ozone inhibition of microorganisms, the first; is that 
ozone attacking protein or lipids of bacterial cell walls or membranes, oxidizing sulfhydryl groups of bacterial enzymes (Victorin, 1992), or by modification of the purine and pyrimidine bases of nucleic acids (Greene et al., 1993).

Ozone applications in food industry are mostly related to decontamination of environments and water treatment. Moreover, ozone has been used with success to inactivate contaminant microflora on meat, poultry, eggs, fish, fruits, vegetables and dry foods. The gas also is useful in detoxification and elimination of mycotoxins and pesticide residues from some agricultural products (Yousef et al., 1999).

The current research aimed to study the effect of gaseous ozone in preservation of chilled poultry and its effect on the quality of chicken meat.

\section{MATERIALS and METHODS}

\section{1- Sampling:}

A total of 24 fresh boneless chicken breasts were purchased from poultry processing plant in Port- Said city, Egypt. The samples were transferred to the lab without delay on ice and each sample was backed into a separate polyethylene bag.

\section{2- Ozonation:}

The samples were divided into 4 groups, the first non-treated group was control; the $2^{\text {nd }}, 3^{\text {rd }}$, and $4^{\text {th }}$ groups were treated with ozone gas at 40, 60, and 70 ppm for $20 \mathrm{~min}$. Ozone gas was generated from a Cold plasma ozone generator ( MA 5001 Model), Germany, using oxygen, with a working voltage of
220 volt, work at ambient temperature, located in Dr. Adel- Abd- Elrahman Clinic, Helioplis, Egypt. Ozone gas treatment was carried out in a glass box where the chicken breasts were placed in

\section{3- Storage Condition:}

After ozone treatment, the non-ozonated and ozonated chicken breasts were transported to the laboratory in packed ice via insulated polystyrene boxes. Samples were subsequently stored in refrigerator maintained at $4 \pm 1^{\circ} \mathrm{C}$.

\section{4- Microbiological analysis:}

Treated and non- treated samples were examined microbiologically for Total bacterial count (FDA, 2001a), Total mould count (FDA, 2001b), and Total Coliforms (FDA, 2002) immediately after treatment and then after $1,3,5,7$, and 9 days of storage at refrigerators.

\section{5- Organoleptic examination}

Chicken breasts were examined by the panelists for any changes in the color, odor and /or texture due to treatment with ozone by the 5 points hedonic scale: 1 , very poor; 2 , poor; 3 common; 4 , good; 5 , very good (Szczesniak, 1987).

\section{6- Statistical analysis:}

The experiment was repeated twice and data were submitted to calculation of means, standard deviations, and the least significant difference test $\mathrm{p} \leq$ 0.05 (Draper and Smith, 1998). All statistical procedures were computed using the Microsoft Excel 2007 in order to compare the mean values of the investigated parameters.

\section{RESULTS}

Table 1: Microbiological evaluation of ozonated and non- ozonated chicken breasts during chilling storage $\left(4 \pm 1^{\circ} \mathrm{c}\right)$ period.

\begin{tabular}{|c|c|c|c|c|c|c|c|c|c|c|c|c|}
\hline \multirow{3}{*}{$\begin{array}{l}\text { Storage } \\
\text { days }\end{array}$} & \multicolumn{4}{|c|}{ Total Bacterial Count (cfu/g) } & \multicolumn{4}{|c|}{ Total Coliforms Count (cfu/g) } & \multicolumn{4}{|c|}{ Total Mould Count (cfu/g) } \\
\hline & \multirow{2}{*}{$\frac{\text { Control }}{0}$} & \multicolumn{3}{|c|}{ Ozone treatment (ppm) } & \multirow{2}{*}{$\frac{\text { Control }}{0}$} & \multicolumn{3}{|c|}{ Ozone treatment (ppm) } & \multirow{2}{*}{$\frac{\text { Control }}{0}$} & \multicolumn{3}{|c|}{ Ozone treatment (ppm) } \\
\hline & & 40 & 60 & 70 & & 40 & 60 & 70 & & 40 & 60 & 70 \\
\hline 0 & $10^{\mathrm{a}}$ & $<10^{\mathrm{b}}$ & $<10^{\mathrm{b}}$ & $<10^{\mathrm{b}}$ & $<10^{\mathrm{a}}$ & $<10^{\mathrm{b}}$ & $<10^{\mathrm{b}}$ & $<10^{\mathrm{b}}$ & $<10^{\mathrm{a}}$ & $<10^{\mathrm{b}}$ & $<10^{\mathrm{b}}$ & $<10^{\mathrm{b}}$ \\
\hline 1 & $3.9 \times 10^{1 \mathrm{a}}$ & $<10^{\mathrm{b}}$ & $<10^{\mathrm{b}}$ & $<10^{\mathrm{b}}$ & $3 \times 10^{1 \mathrm{a}}$ & $<10^{\mathrm{b}}$ & $<10^{\mathrm{b}}$ & $<10^{\mathrm{b}}$ & $1.1 \times 10^{1 \mathrm{a}}$ & $<10^{\mathrm{b}}$ & $<10^{\mathrm{b}}$ & $<10^{\mathrm{b}}$ \\
\hline 3 & $4.1 \times 10^{2 \mathrm{a}}$ & $2.1 \times 10^{1 \mathrm{~b}}$ & $1.4 \times 10^{1 \mathrm{~b}}$ & $<10^{\mathrm{c}}$ & $9.6 \times 10^{1 \text { a }}$ & $3.9 \times 10^{1 \mathrm{~b}}$ & $1.9 \times 10^{1 \mathrm{c}}$ & $10^{\mathrm{d}}$ & $5 \times 10^{1 \mathrm{a}}$ & $3.1 \times 10^{1 \mathrm{~b}}$ & $2.9 \times 10^{1 \mathrm{~b}}$ & $1.4 \times 10^{1 \mathrm{c}}$ \\
\hline 5 & $2.8 \times 10^{4 \mathrm{a}}$ & $2.2 \times 10^{2 b}$ & $1.9 \times 10^{2 \mathrm{c}}$ & $9 \times 10^{1 \mathrm{~d}}$ & $6.2 \times 10^{2 \mathrm{a}}$ & $2.3 \times 10^{2 \mathrm{~b}}$ & $1.4 \times 10^{2 \mathrm{c}}$ & $2.8 \times 10^{1 \mathrm{~d}}$ & $2.7 \times 10^{2 \mathrm{a}}$ & $9.7 \times 10^{1 \mathrm{~b}}$ & $7.6 \times 10^{1 \mathrm{c}}$ & $5.8 \times 10^{1 \mathrm{~d}}$ \\
\hline 7 & $7.8 \times 10^{5 \mathrm{a}}$ & $7.4 \times 10^{3 \mathrm{~b}}$ & $2.9 \times 10^{3 \mathrm{c}}$ & $3.4 \times 10^{2 \mathrm{~d}}$ & $5.5 \times 10^{3 \mathrm{a}}$ & $9.1 \times 10^{2 b}$ & $8.4 \times 10^{2 \mathrm{c}}$ & $6.5 \times 10^{2 \mathrm{~d}}$ & $9.6 \times 10^{4 a}$ & $6.3 \times 10^{2 b}$ & $5.4 \times 10^{2 \mathrm{c}}$ & $1.9 \times 10^{2 \mathrm{~d}}$ \\
\hline 9 & $\mathrm{R}$ & $8.8 \times 10^{4 a}$ & $6.2 \times 10^{4} \mathrm{~b}$ & $2.4 \times 10^{4 c}$ & $\mathrm{R}$ & $3.5 \times 10^{3 \mathrm{a}}$ & $1.1 \times 10^{3 \mathrm{~b}}$ & $10^{3 \mathrm{c}}$ & $\mathrm{R}$ & $4.2 \times 10^{3 \mathrm{a}}$ & $2.6 \times 10^{3 \mathrm{~b}}$ & $1.4 \times 10^{3 \mathrm{c}}$ \\
\hline
\end{tabular}

ND: Not Detected R: Rejected ( according to EOS- 1090/2005)

Different litters within the same row in the same feature are significantly different $(\mathrm{P} \leq 0.05)$ 
Table 2: Organoleptic evaluation of ozonated and non- ozonated chicken breasts during chilling storage $\left(4 \pm 1^{\circ} \mathrm{c}\right)$ period.

\begin{tabular}{|c|c|c|c|c|c|c|c|c|c|c|c|c|}
\hline \multirow{3}{*}{$\begin{array}{l}\text { Storage } \\
\text { days }\end{array}$} & \multicolumn{4}{|c|}{ Color } & \multicolumn{4}{|c|}{ Odor } & \multicolumn{4}{|c|}{ Texture } \\
\hline & \multirow{2}{*}{$\begin{array}{c}\text { Control } \\
0\end{array}$} & \multicolumn{3}{|c|}{ Ozone treatment (ppm) } & \multirow{2}{*}{$\begin{array}{c}\text { Control } \\
0\end{array}$} & \multicolumn{3}{|c|}{ Ozone treatment (ppm) } & \multirow{2}{*}{$\begin{array}{c}\text { Control } \\
0\end{array}$} & \multicolumn{3}{|c|}{ Ozone treatment (ppm) } \\
\hline & & 40 & 60 & 70 & & 40 & 60 & 70 & & 40 & 60 & 70 \\
\hline 0 & $4.9 \pm 0.02^{\mathrm{a}}$ & $4.84 \pm 0.01^{\mathrm{a}}$ & $4.81 \pm 0.10^{\mathrm{a}}$ & $4.85 \pm 0.11^{\mathrm{a}}$ & $4.5 \pm 0.11^{\mathrm{b}}$ & $4.88 \pm 0.12^{\mathrm{b}}$ & $4.72 \pm 0.02^{\mathrm{b}}$ & $4.74 \pm 0.13^{\mathrm{b}}$ & $4.89 \pm 0.01^{\mathrm{c}}$ & $4.8 \pm 0.11^{\mathrm{c}}$ & $4.9 \pm 0.02^{\mathrm{c}}$ & $4.85 \pm 0.10^{\mathrm{c}}$ \\
\hline 1 & $4.91 \pm 0.14^{\mathrm{a}}$ & $4.82 \pm 0.03^{\mathrm{a}}$ & $4.9 \pm 0.12^{\mathrm{a}}$ & $4.88 \pm 0.2^{\mathrm{a}}$ & $4.6 \pm 0.01^{\mathrm{b}}$ & $4.76 \pm 0.13^{\mathrm{b}}$ & $4.77 \pm 0.10^{\mathrm{b}}$ & $4.68 \pm 0.12^{\mathrm{b}}$ & $4.79 \pm 0.03^{\mathrm{c}}$ & $4.6 \pm 0.32^{\mathrm{c}}$ & $4.8 \pm 0.04^{\mathrm{c}}$ & $4.8 \pm 0.13^{\mathrm{c}}$ \\
\hline 3 & $4.2 \pm 0.31 *$ & $4.74 \pm 0.12^{\mathrm{a}}$ & $4.71 \pm 0.1^{\mathrm{a}}$ & $4.7 \pm 0.24 \mathrm{a}$ & $4.5 \pm 0.23^{\mathrm{b}}$ & $4.64 \pm 0.20^{\mathrm{b}}$ & $4.6 \pm 0.01 \mathrm{~b}$ & $4.61 \pm 0.04^{\mathrm{b}}$ & $4.3 \pm 0.60^{* * *}$ & $4.5 \pm 0.01^{\mathrm{c}}$ & $4.5 \pm 0.14^{\mathrm{c}}$ & $4.6 \pm 0.03^{\mathrm{c}}$ \\
\hline 5 & $4 \pm 0.5^{*}$ & $4.61 \pm 0.04^{\mathrm{a}}$ & $4.63 \pm 0.2^{\mathrm{a}}$ & $4.64 \pm 0.11^{\mathrm{a}}$ & $2.6 \pm 0.25 * *$ & $4.3 \pm 0.6^{\mathrm{b}}$ & $4.4 \pm 0.03^{b}$ & $4.4 \pm 0.01^{\mathrm{b}}$ & $3.5 \pm 0.111^{* * * *}$ & $4.4 \pm 0.31^{\mathrm{c}}$ & $4.3 \pm 0.23^{\mathrm{c}}$ & $4.4 \pm 0.12^{\mathrm{c}}$ \\
\hline 7 & $3.1 \pm 0.15^{*}$ & $4.3 \pm 0.07^{\mathrm{a}}$ & $4.2 \pm 0.30^{\mathrm{a}}$ & $4.5 \pm 0.11^{\mathrm{a}}$ & $1.7 \pm 0.30 * *$ & $3.5 \pm 0.02^{\mathrm{b}}$ & $3.6 \pm 0.14^{\mathrm{b}}$ & $3.8 \pm 0.54^{\mathrm{b}}$ & $1.8 \pm 0.22 * * *$ & $3.4 \pm 0.31^{\mathrm{c}}$ & $3.2 \pm 0.14^{\mathrm{c}}$ & $3.2 \pm 0.16^{\mathrm{c}}$ \\
\hline 9 & $2.1 \pm 0.17 *$ & $3.2 \pm 0.01^{\mathrm{a}}$ & $3.4 \pm 0.5^{\mathrm{a}}$ & $3.5 \pm 0.26^{\mathrm{a}}$ & $0.98 \pm 0.45^{* *}$ & $3.1 \pm .61^{b}$ & $3.2 \pm 0.42^{\mathrm{b}}$ & $3.17 \pm 0.35^{\mathrm{b}}$ & $1.2 \pm 0.13^{* * *}$ & $2.9 \pm 0.34^{\mathrm{c}}$ & $2.6 \pm 0.45^{\mathrm{c}}$ & $2.8 \pm 0.25^{\mathrm{c}}$ \\
\hline
\end{tabular}

Different superscription within the same raw and the same feature are significantly different $\mathrm{p} \leq 0.05$.

\section{DISCUSSION}

The data presented in (Table 1) clearly showed the efficacy of gaseous ozone to reduce the counts of microorganism of chicken breast samples. Immediately after treatment, Microbial populations it is $<10^{-1}$ by the used methods in the ozonated chicken breasts. After storage of the samples at $4^{\circ} \mathrm{c}$ for one day there were slight increase in the microbial populations of treated groups (but still less than 10 $\mathrm{cfu} / \mathrm{g})$ and non- treated one. At first ( 0 and $1^{\text {st }}$ day of storage) there were not significant differences $(\mathrm{p} \leq$ 0.05) in the cfu/g of TBC, TCC, and TMC between the treated groups but from the $3^{\text {rd }}$ day of storage until the end of the storage period there were indirect proportions between the dose of ozone and the microbial count (i.e. increased ozone dose decreased the microbial populations). The microbial populations increased gradually during the storage period. At the $7^{\text {th }}$ day of storage the control (nontreated) group was rejected because the microbial populations (TBC, TCC, and TMC) reached $7.8 \times 10^{5}$, $5.5 \times 10^{3}$ and $9.6 \times 10^{4}$ respectively; while the treated groups were still within the permissible limits approved by the (EOS-1090/2005) after 9 days of storage. These results indicated that treatment with 40, 60, and $70 \mathrm{ppm}$ of ozone for 20 minutes increased the shelf-life of the chicken breasts. The obtained results come in parallel with Nieto et al. (1984) who observed that ozone has a pronounced effect on the flora causing deterioration and had prolonged the useful- life of poultry in refrigerated storage and Sharma and Hudson (2008) who concluded that ozone at $25 \mathrm{ppm}$ reduced the population of 15 bacterial spp. including Gram positive and Gram negative bacteria by more than 3 $\log \mathrm{cfu} / \mathrm{ml}$. Also Yang and Chen (2007) stated that ozone treated broiler parts had consistently lower microbial counts than the control parts during the entire refrigerated period. They added that the broiler parts treated with ozone had extended shelf- life for 2.4 days. Jindal et al. (1995) studied the effect of ozone on drumstick and they observed that ozone reduced the levels of aerobic plate count, coliforms, and $E$. coli by more than one log and extended the shelf-life for as much as two days. Graham (2000) also concluded that ozonation of poultry carcasses is a suitable treatment process for reducing spoilage and pathogenic microorganisms. In a study conducted by Sheldon and Brown (1986) the microbiological load of the chicken carcasses bathed in ozonated water was two logarithmically times lower as compared with non treated one.

In addition, Data of the sensory analysis in (Table 2) showed that ozone treatment had no negative effects on the quality of the chicken breasts including color, odor, and texture but also prolonged the acceptable features by more than 9 days. As off odors and slime caused by microorganisms when populations reach approximately $10^{7}$ to $10^{8} \mathrm{cfu} / \mathrm{g}$ (James 2004). The obtained results are in agreement with several studies done to study the effect of ozone treatment on the quality characteristics of poultry, meat, and fish by Sheldon and Brown (1986); Graham (1997); Graham (2000); Leusink and Karf (2000); Maris et al. (2000); Al- Haddad et al. (2005); Perry and Yousef (2011). 


\section{CONCLUSIONS}

All data as summarized in this paper have shown the effectiveness of gaseous ozone like a promising broad spectrum antimicrobial agent (significant potential gains in shelf life and quality production) that should be considered as part of the any poultry processing sanitation protocol.

\section{REFERENCES}

Al-Haddad, K.S.H.; Al-Qassemi, R.A.S. and Rabison, R.K. (2005): The use of gaseous ozone and gas packaging to control populations of Salmonella infantis and Pseudomonas aeruginosa on chicken portions. J. Food Control, 16: 405-410.

Allen, V.M.; Corry, J.E.L.; Burton, C.H.; Whyte, R.T. and Mead, G.C. (2000): Hygiene aspects of modern poultry chilling, Int. J. of Food Microbio., 58: 39-48.

Anonymous (2002): California Energy Commission. Final Report.Aplications of ozonation and membrane treatment in poultryprocessing.

Cevger, Y.; Sarlözkan, S. and Güler, H. (2002): The effect of the sale of whole or cut up chicken meat on enterprise income according to season. Turk J. Vet. Anim. Sci. 28: 399-402

Chang, Y.H. and Sheldon, B.W. (1989): Application of ozone with physical wastewater treatments to recondition poultry process waters. Poultry Sci. 68: 1078-1087.

Draper, N.R. and Smith, H. (1998): Applied Regression Analysis. $3^{\text {rd }}$ Edn., John Wiley, New York, pp: 131-153.

Erickson, M.C. (1999): Flavor quality implications in chlorination of poultry chiller water. Food Research International, 32: 635-641.

EOS (Egyptian Organization for Standardization) (2005): Sanitation and quality control of Poultry and Rabbits No 1090/ 2005.

FDA (2001 a): BAM, Aearobic Plate Count. Bacteriological Analytical Manual, $8^{\text {th }}$ Ed., Rev. A, 1998. Chapter 3. Authors: Maturin L, and Peeler J. T.

FDA (2001b): Yeast, Mould and Mycotoxins. Bacteriological Analytical Manual, $8^{\text {th }}$ Ed., Rev. A, 1998. Chapter 18. Authors: Tournas V, Stack M.E., Mislivec P.B., and Bandler R.

FDA (2002): Enumeration of Escherichia coli and the Coliforms. Bacteriological Analytical Manual, $8^{\text {th }}$ Ed., Rev. A, 1998. Chapter 4. Authors: Feng P, Weagant S.D., and Grant M.A.

Graham, D.M. (1997): Use of ozone for processing. Food Technol., 51: 72-75.

Graham, D.M. (2000): Ozone as an antimicrobial agent for the treatment, storage and processing of foods in gas and aqueous phases. Direct
Food Additive Petition, FD A, Department of Health and Human Services, Washington, DC 20204.

Greene, A.K.; Few, B.K. and Serafini, J.C. (1993): A comparison of ozonation and chlorination for disinfection of stainless steel surfaces. J. Dairy Sci., 76: 3617-3620.

Guzel-Seydim, Z.; Bever, P. and Greene, A.K. (2004): Efficacy of ozone to reduce bacterial populations in the presence of food components. J. Food Microbiol., 24: 475-479.

Horvath, M.; Bilitizky, I. and Huttner, J. (1985): In Ozone. Elsevier, Amsterdam, Netherlands.

James, S. (2004): Poultry refrigeration. Chapter 4, In: Poultry meat processing and quality. $2^{\text {nd }}$ edition, Edited by Mead, G.C., Publ. by Wood head Publishing Limited and CRC Press LLC.

Jindal, V.; Waldroup, A.L. and Forsythe, R.H. (1995): Ozone and improvement of quality and shelf life of poultry products. J. Appl. Poult. Res. Fall., 4(3): 239-248.

Leusink, J. and Karf, G. (2000): Efficacy of gaseous ozone against generic E. coli in ground beef. Ozone Solutions Inc., http//www. Ozonesolutions.com

Maris, P.; Nash, B.; Blakistone, B.; Yuan, J. and Bolton, G. (2000): Evaluation of ozone as a disinfecting agent to enhance the quality and extend the shelf life of row, vacuum-packed fish. A seafood technology research project funded by the North Carolina Fishery Resource Grant Program. FRG 99- ST- 04.

Mielcke, J. and Ried, A. (2004): Current state of application of ozone and UV for food processing. Paper presented at Proceedings of the Food Protection International Conference 2004. Monte da Caparica, Portugal, 20-22 of May 2004.

Nieto, J.C.; Jienez-Colmenero, F. and Pelaez, M.C. (1984): Effect of ozone on bacterial flora in poultry during refrigerated storage. Inter. J. of Refrigeration, 7(6): 389-392.

Perry, J.J. and Yousef, A.E. (2011): Decontamination of Raw Foods using Ozone- Based Sanitization Techniques. Annual Rev. food Sci., Technol., 2: 281-298.

Rio, E.; Capita, R.; Prieto, M. and Alanso-Calleja, C. (2006): Comparison of pathogenic and spoilage bacterial levels on refrigerated poultry parts following treatment with trisodium phosphate, Food Microbiology 23(2): 195-198.

Şengör, E. (2002): Türk tavukçuluk sektörünün durumu ve dünya ile karşılaştırma. Gıda Teknolojisi 6(9):18-20.

Sheldon, D.W. and Brown, A.L. (1986): Efficacy of ozone as a disinfectant for poultry carcasses and chill water. J. Food Sci., 51: 305-309. 
Sharma, M. and Hudson, J.B. (2008): Ozone gas is an effective and practical antibacterial agent. Appl. Epid. Health Care Set. Comm., 36(8): 559-563.

Szczesniak, A.S. (1987): Correlation sensory with instrumental texture measurements: An overview of recent developments. J. Tex Studies 19(1): 51-59

Tosun, H. and Tamer, A. ̈. (2000): Soğutma işleminin kanatlı karkasının mikrobiyal kalitesine etkisi ile laktik asitle yüzey Dekontaminasyonu üzerine araştırmalar. Turk J. Vet. Anim. Sci 24; 517-521

USDA (1997): Code of Federal Regulations. Title 9, Part 381-66. Poultry products: Temperatures and chilling and freezing procedures. Office of the Federal Register National Archives and Records Administration. Washington, DC.

Vaz-Velho, M.; Peterson, M.L.; Harder, S.; Rummo, N. and House, D. (2006): Inactivation by ozone of Listeria innocuaon salmon-trout during cold-smoke processing, Food Control, 17: 609-616.

Victorin, K. (1992): Review of the genotoxicity of ozone. Mutation Research, 227: 221-238.

Whistler, P.E. and Sheldon, B.W. (1989): Biocidal activity of ozone versus formaldehyde against poultry pathogens inoculated inprototype seter. Poultry Science 68: 1068-1073.

Yang, P.P.W. and Chen, T.C. (2007): Effects of ozone treatment on microflora of poultry meat. J. Food Process. Preserv., 3(2): 177-185.

Yousef, A.E.; Kim, J-G. and Dave, S. (1999): "Application of ozone for enhancing the microbiological safety and quality of foods-a review", J. Food Prot., Vol. 62, No. 9, pp. 1071-1087.

Zentox Corporation (2007): Ozone in Food Processing Applications: Past Experience, Future Potential andRegulatory Issues. Available at<http://www.novazone.net/library/Ozofood. p ch, 277: 221-238.

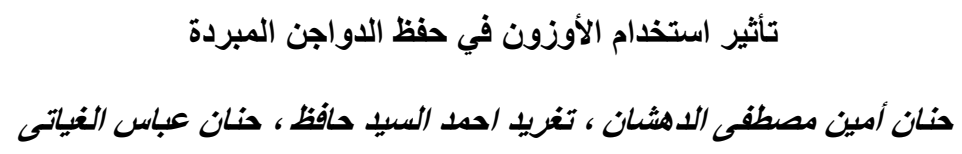

تم دراسة تأثير استخدام غاز الأوزون فى معالجة صدور الدجاج المخلية على أعداد الميكروبات وذللك لمعرفة تأثيرة على حفظ الدجاج المباج المبرد

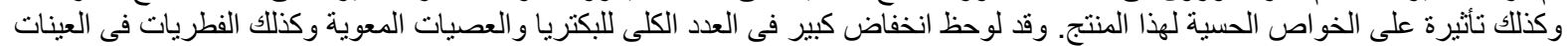

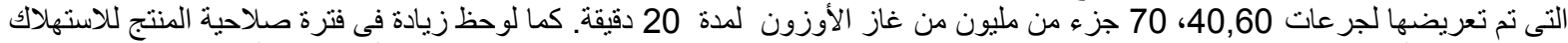

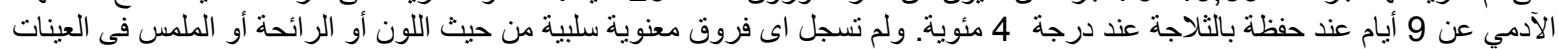

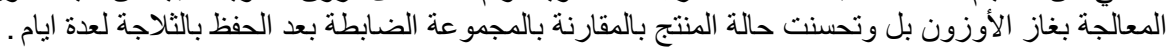

